\title{
Federal Regulation of Air Transportation and the Environmental Impact Problem
}

The only thing that can drown out a jet aircraft on take-off, Secretary of Transportation Alan S. Boyd has said, is "the roar of protest from outraged citizens who live in airport neighborhoods." 1 Both the aircraft and the people are getting louder, and there is little immediate prospect of a technological breakthrough that will quiet them. Present estimates are that a quieter jet aircraft engine will not be feasible before the 1970's. ${ }^{2}$ By that time, the supersonic transport threatens to make the sonic boom an ordinary occurrence, and craft capable of operating from rooftop airports may well introduce air transportation, and a new noise source, into downtown areas. ${ }^{3}$ There is widespread recognition that something must be done to identify and deal with the unwanted byproducts of aviation. ${ }^{4}$

1 Samuelson, The SST and the Government: Critics Shout Into a Vacuum, 157 ScneNce 1146,1149 (1967). One indication of the magnitude of the protest is that more than 175 suits are pending against 34 airport authorities, with damage claims adding to millions of dollars. 1 CCH Clean AIR News No. 39, at 8 (Oct. 17, 1967). Private actions for damages from intrusive overflights are the subject of numerous law review articles, including: Harvey, Landowners' Rights in the Air Age: The Airport Dilemma, 56 Mich. L. REv. 1313 (1958); Hill, Liability for Aircraft Noise-The Aftermath of Causby and Griggs, 19 U. Mrami L. REv. 1 (1964); Spater, Noise and the Law, 63 Mrch. L. REv. 1373 (1965); Tondel, Noise Litigation at Public Airports, 32 J. ArR L. \& CoMr. 387 (1966); Note, Airplane Noise, Property Rights, and the Constitution, 65 CoLum. L. Rev. 1428 (1965); Note, Airplane Noise: Problem in Tort Law and Federalism, 74 HARv. L. Rev. 1581 (1961); Note, Jet Noise in Airport Areas: A National Solution Required, 51 MrN. L. REv. 1087 (1967).

2 For a description of current federal research and development programs aimed at the noise problem, see 113 CoNG. REc. H12607 (daily ed. Sept. 27, 1967); Hearings on H.R. 4450, H.R. 6470 Before the Subcomm. on Advanced Research \& Technology, House Comm. on Science \& Astronautics, 90th Cong., 1st Sess., pt. 4, at 364-78, 391-406 (1967) [hereinafter cited as House 1968 NASA Authorization Hearings]; Hornig, Report to the President, 3 WWerty CompIL. Pres. Docs. 527-28 (1967).

3 On the SST, see Hearings on H.R. 11456 Before the Subcomm. of the Senate Comm. on Appropriations, 90th Cong., Ist Sess. 385-444 (1967) (FAA presentation) [hereinafter cited as Senate 1968 DOT Appropriations Hearings]; id. at 557-89 (testimony of Senator William Proxmire and Bo Lundberg); Hearings on Dep't of Transp. Appropriations for 1968 Before a Subcomm. of the House Comm. on Appropriations, 90th Cong., Ist Sess. 278-350 (1967) (FAA presentation) [hereinafter cited as House 1968 DOT Appropriations Hearings]. On VTOL aircraft, see notes $44-50$ and accompanying text infra. See also House 1968 NASA Authorization Hearings, supra note 2, pt. 4, at 40-42, 351-56, on federal V/ STOL research. The FAA is also actively engaged in V/STOL research. See House 1968 DOT Appropriations Hearings, supra at 222-23.

4 See Aircraft Noise and Land Use Near Airports, 3 Weekly CompIL. Pres. Docs. 527 
Aviation is extensively regulated by the federal government. The Civil Aeronautics Board is charged with "economic" regulation of air transportation, ${ }^{5}$ the Federal Aviation Administration in the Department of Transportation with "safety" regulation of aviation. ${ }^{8}$ Noise and other environmental consequences ${ }^{7}$ of aircraft operation do not fall squarely within either category. They are not regulated directly, and little has been done indirectly to require their abatement.

The Civil Aeronautics Board determines whether to authorize the institution of air carrier service between designated points. ${ }^{8}$ It has not considered environmental impact pertinent to these determinations. In a new route proceeding, the Board has held:

[A]ny issues of environmental impact . . . at best can involve only questions of the general effect of operations by particular types of aircraft at various altitudes adjacent to or over congested areas....

The "factors which most directly relate" to environmental impact are the location of airports or landing areas and flight patterns, according to the Board. Neither, it indicated, is at issue in its proceedings. ${ }^{9}$

(1967) (Memorandum from the President to Heads of Departments and Agencies); Federal Aircraft Noise Program Management Committee, Status of the Federal Aircraft Noise Abatement Program, Feb، 1, 1967, reprinted in House 1968 NASA Authorization Hearings, supra note 2, pt. 4, at 365 and 473; H.R. Doc. No. 399, 89th Cong.s 2d Sess. 12 (1966) (President's message on transportation), See generally Special Subcomm. on Regulatory Agencies, House CoMm. on INTERSTate \& Foreign CoMmerce, Investigation and STUdy of Aircraft Noise Problems, H.R. Rep. No. 36, 88th Cong., 1st Sess. (1963); U.S. Office of Science \& Technology, Jet AIrcraft Noise Panel, Alleviation of Jet Aircraft Nolse NEAR AIRPORTS (1966).

5 See Federal Aviation Act of 1958, 49 U.S.C. \$§ 1301-1542 (1964), especially tit. IV, 49 U.S.G. §§ 1371-87.

6 See id., especially tit. II, 49 U.S.C. $\S \S 1341-55$, and tit. VI, 49 U.S.G. $\S \S 1421-30$.

7 On air pollution from aircraft, see U.S. Public Healtr SERv, Drv. OF ATR Pollution, A Survey of AIR Pollutton in Communtties Around the John F, Kennedy Int'l AIRPORT (1966).

8 Federal Aviation Act of 1958, $\$ 401,49$ U.S.C. $\$ 1371$ (1964). Not all intrusive aircraft are operated by domestic air carriers subject to this regulation. Some air transportation is exempted by the Board under $i d . \$ 416(\mathrm{~b})$, 49 U.S.G. § 1386(b); foreign air transportation presents additional problems of which the President is final arbiter. See id. \$\$ 402, 801,49 U.S.C. $\$ \S 1372,1461$. General aviation is subject to FAA, but not CAB, regulation. Military aircraft, controlled to some extent by FAA regulation, are not considered in this comment.

9 Washington/Baltimore Helicopter Serv. Investigation, GAB Order No. E-25704 (Sept. 19, 1967). The issue was before the Board on petitions for review of denial of intervention in a helicopter certification proceeding filed by citizens' groups. The petitioners alleged that they had a substantial interest in the proceeding, a requirement for intervention under the Board's Rules of Practice, 14 C.F.R. $\$$ 302.15(b) (1967), based on the erivironmental impact on them of the proposed service.

The Board held, 3-2, that formal intervention was properly denied these petitioners. The majority found that the petitioners failed to allege "any unique injury which will 
The Department of Transportation does not agree. It has argued to the Board that consideration of environmental impact-and specifically noise and air pollution-is a relevant and important factor to be weighed in determining whether to authorize air service. ${ }^{10}$ But the Department construes its own authority to consider noise output narrowly. The Federal Aviation Administration considers noise in formulating flight procedures, but not in licensing equipment or assigning airways to carriers. ${ }^{11}$ It has requested legislative authorization to establish noise standards and criteria and apply them to equipment certification. ${ }^{12}$ Noise abatement flight procedures, it contends, are a "poor substitute" for certification authority because they do not include "many of the incentives for quiet operation which can be built into certification rules." 13

The power of localities to adopt noise abatement ordinances aimed

not be shared equally by all similarly situated property owners" and made "no showing that the environmental impact of helicopter operations may be expected to differ from that inflicted by other aircraft which may pass at low altitudes over residential areas" or that a helicopter proceeding "is essentially different in this respect from any other new route case."

Primarily, however, the Board relied on its holding that airport location and flight paths are not at issue to find that any potential injury to the petitioners is "both remote and speculative." Participation by the Department of Transportation, and by the petitioners on an informal basis, the Board held, "may be expected to amply articulate the broad public interest in environmental impact." The Board buttressed its conclusion with the argument that there are "undoubtedly thousands" of residents and property owners whose interests will be remotely affected by additional service at metropolitan airports. These persons will have different interests; if each were allowed to intervene formally "proceedings which are already burdened by numerous parties would become nearly uncontrollable."

In petitioners' appeal from the Board's order, the Department of Justice takes the position that intervention was improperly denied. Brief for Respondent at 35, Palisades Citizens Ass'n, Inc. v. CAB, No. 21422 (D.C. Cir. filed Nov. 13, 1967).

10 Answer of the Dep't of Transportation to Petitions for Review of Staff Action Filed by the Committee Against National, Concerned Citizens, the Palisades Citizens Association, Washington-Baltimore Helicopter Service Investigation, CAB Docket No. 17665, at 2 (Aug. 10, 1967), reprinted in 113 Conc. Rrc. H12619 (daily ed. Sept. 27, 1967) [hereinafter cited as DOT Helicopter Answer].

11 Under Federal Aviation Act of 1958, §§ 307, 603, 604, 49 U.S.C. $\S \S 1348,1423,1424$. See notes 86-90 and accompanying text infra.

12 S. 3591, H.R. 16171, 89th Cong., 2d Sess. (1966); S. 707, H.R. 3400, 90th Cong., 1st Sess. (1967). As introduced, the legislation would cover all title VI certifications, including air carrier operating-as well as aircraft, equipment, and airworthiness-certificates. Hearings were held before the Transportation and Aeronautics Subcommittee of the House Interstate and Foreign Commerce Committee in October 1966 and in November 1967. On the latter hearings, see N.Y. Times, Nov. 15, 1967, at 1, col. 7; id., Nov. 16, 1967, at 1 , col. 7; id., Nov. 17, 1967, at 40, col. 3 .

13113 Cong. Rrc. A4216 (daily ed. Aug. 18, 1967) (letter from Secretary of Transportation Alan S. Boyd to Representative Herbert Tenzer). See also House 1968 NASA Authorization Hearings, supra note 2, pt. 4, at 374-75, 387-89, 436, 444, 445-46. 
at or including aircraft operations is extremely limited. Because federal regulation of air transportation is so extensive, local regulation at variance with it may be unconstitutional. "Local initiative in noise control of aviation," one district court recently held, "cannot coexist with a comprehensive system of federal regulation" of air transportation, ${ }^{14}$ despite the failure of that system to deal with noise effectively.

This comment is concerned with the extent of the authority of the Civil Aeronautics Board and the Federal Aviation Administration to consider noise in their respective certification proceedings. The argument is advanced that, even under present legislation, the Board must and the Administrator may ${ }^{15}$ consider the environmental impact of air transportation. Amendment of the Federal Aviation Act to clarify this authority may be desirable. Unless such legislation is carefully drafted, however, the results may be discouraging to opponents of aircraft noise.

Section 401 of the Federal Aviation Act provides that no air carrier shall engage in air transportation unless authorized to do so by the Civil Aeronautics Board. ${ }^{\mathbf{1 6}}$ Authorization is dependent upon a finding that the transportation is "required by the public convenience and necessity." 17

"Public convenience and necessity" is not wholly undefined in the Act. Section 102 requires the Board to consider several enumerated criteria "among other things" in accordance with the public con-

14 American Airlines, Inc. v. Town of Hempstead, 272 F. Supp. 226, 235 (E.D.N.Y. 1967).

15 The distinction between compulsion and discretion is primarily a matter of who has standing to raise the issue before the Board, on the one hand, and the Administrator of the FAA, on the other. Whether persons may intervene solely on the environmental impact issue-a contention the Board answered negatively (see note 9 supra)-is presently $s u b$ judice. No matter how that appeal may be decided, there are parties in a CAB proceeding, with a substantial interest on grounds independent of environmental impact, who might raise the issue before the Board and on appeal to the courts. For example, municipalities to which service is proposed may intervene under Board Rule of Practice 15(b), 14 C.F.R. $\$ 302.15(b)$ (1967). While none has raised the environmental impact issue, and few may be expected to, as intervenors they have standing to do so. See Juarez Gas Co., S.A. v. FPC, 375 F.2d 595 (D.C. Cir. 1967); Office of Communications of Church of Christ v. FCC, 359 F.2d 994 (D.C. Cir. 1966); Scenic Fudson Preservation Conf. v. FPC, 354 F.2d 608 (2d Cir. 1965), cert. denied, 384 U.S. 941 (1966). This is not necessarily true in FAA rule-making and certification proceedings. Standing to intervene and to appeal FAA orders is much more limited, at least on the face of the statutory and administrative provisions.

16 Section 401(a), 49 U.S.C. § 1371(a) (1964).

17 Section 401(d)(1), 49 U.S.C. $\$ 1371$ (d)(1) (1964). Authorization also requires a finding that the carrier is "fit, willing, and able to perform such transportation." Id. 
venience and necessity. ${ }^{18}$ Two of these criteria-the encouragement and development of an air transportation system "properly adapted to the present and future needs" of commerce, the postal service, and defense and regulation in such manner as to "recognize and preserve the inherent advantages" of air transportation-appear to suggest that regulation should aim at maximizing the benefits and minimizing the detriments of air service. A "properly adapted" system implies a broad view of national transportation needs; recognition of "inherent advantages" presupposes comparison with other transport modes and realization that aviation's advantages are not unlimited. Moreover, because the enumerated factors are not exclusive, it has been argued that environmental impact is among the "other things" the Board is directed to consider. ${ }^{10}$

Congress intended that the Board consider factors beyond its regulatory control in public convenience and necessity determinations. The Federal Aviation Act transferred the Board's authority over air safety to the FAA; ${ }^{20}$ nevertheless, section 102(e) requires the Board to consider the promotion of air safety in accord with the public convenience and necessity. ${ }^{21}$ Similarly, even if it is concluded that the Board is without authority to regulate environmental impact, it does not follow that it may neglect this factor. ${ }^{22}$

18 Section 102, as codified, reads as follows:

In the exercise and performance of its powers and duties under this chapter, the Board shall consider the following, among other things, as being in the public interest, and in accordance with the public convenience and necessity:

(a) The encouragement and development of an air transportation system properly adapted to the present and future needs of the foreign and domestic commerce of the United States, of the Postal Service, and of the national defense;

(b) The regulation of air transportation in such manner as to recognize and preserve the inherent advantages of, assure the highest degree of safety in, and foster sound economic conditions in, such transportation, and to improve the relations between, and coordinate transportation by, air carriers;

(c) The promotion of adequate, economical, and efficient service by air carriers at reasonable charges, without unjust discriminations, undue preferences or advantages, or unfair or destructive competitive practices;

(d) Competition to the extent necessary to assure the sound development of an air-transportation system properly adapted to the needs of the foreign and domestic commerce of the United States, of the Postal Service, and of the national defense;

(e) The promotion of safety in air commerce; and

(f) The promotion, encouragement, and development of civil aeronautics.

49 U.S.C. \& 1302 (1964).

19 DOT Helicopter Answer, supra note 10, at 2.

20 Other than investigation of accidents under title VIr, 49 U.S.C. $\$ \S 1441-1443$ (1964) and appeals from FAA determinations under title VI, § 609, 49 U.S.C. § 1429 (1964), functions transferred to the National Transportation Safety Board in 1966. Department of Transportation Act $\S 6(d), 49$ U.S.C. \& 1655(d) (Supp. 1966).

21 See H.R. Rep. No. 2360, 85th Cong., 2d Sess. 12 (1958).

22 It is here contended that the Board has some indirect regulatory control over environmental impact. See notes 65-82 and accompanying text infra. 
In the Department of Transportation Act, Congress declared that the national transportation policy includes maximum conservation of historic sites, recreation areas, and natural beauty. ${ }^{23}$ Congress has stressed the importance of compatible land use around airports ${ }^{24}$ and indicated its concern with the airport noise problem. ${ }^{25}$ While few provisions of this recent legislation directly apply to the Board,26 national policy is relevant to the scope of public convenience and necessity.

"Public convenience and necessity" has a long history of judicial and administrative interpretation. Most of the case law is unrelated to the composition of the "public" to which the term of art applies. Most often, the public is affected only as consumers of the regulated service; only infrequently have courts or regulatory agencies been asked to construe the phrase as involving a weighing of benefits to the consuming public against costs to other members of the public. In the ordinary proceeding, opposition, if any, is not to the service as such but to the adverse effect of its authorization on competitors. Convenience and necessity of the service to the users is presumed. The determination is limited to consideration of its economic impact on the regulated industry. ${ }^{27}$ In this setting, alternative means of providing the service, or need for the service at all, are not usually explored.

The assumption that regulatory agencies may disregard benefits and detriments external to the regulated industry has come under increasing scrutiny by the courts. They have recognized that the public interest or public convenience and necessity cannot be so easily

23 Department of Transportation Act $\S \S 2(a),(b)(2), 4(t), 49$ U.S.C. $\S \S 1651(a),(b)(2)$, 1653(f) (Supp. 1966). See S. REp. No. 1659, 89th Cong., 2d Sess. 5-6 (1966).

24 Federal Airport Act $\S \S 9(d)(3), 11(4), 49$ U.S.C. $\$ \S 1108(d)(3), 1110(4)$ (1964). See 14 G.F.R. §§ 151.26(a), (b), 151.39(a)(4), (5) (1967).

25 Department of Transportation Act § 4(a), 49 U.S.C. § 1653(a) (Supp. 1966) (authorizing DOT research and development in noise abatement, "with particular attention to aircraft noise'); Housing and Urban Development Act of 1965 \& 1113, 12 U.S.C. § 1701d-3 note (Supp. 1966), as amended by Pub. L. No. 90-19, \& 22(h), 81 Stat. 27 (1967) (authorizing HUD study of feasible methods of reducing economic loss and hardship suffered by homeowners as a result of depreciation following the construction of airports near their homes, including methods of noise insulation). The latter study has been published. U.S. Dep'T of Housing and Urban Dev., Federal Housing AdMin., Insulating Homes FROM AIRGRAFT NOISE (1967).

26 Section 106 of the Historic Sites Preservation Act, 16 U.S.C. $\$ 470 f$ (Supp. 1966), does apply directly to the Board. It requires that a federal department or independent agency, before issuing any license, take into account the effect of the proposed undertaking on any historic site and afford the Advisory Council on Historic Preservation an opportunity to comment. $C f$. the use made of the Anadromous Fish Act of 1965, 16 U.S.C. $\S \S 757 a-757 f$ (Supp. 1966), in Udall v. FPC, 387 U.S. 428, 438-40 (1967), discussed at notes 28-32 and accompanying text infra.

27 Cf. Reich, The Law of the Planned Society, 75 YALE L.J. 1227, 1238-47 (1966). 
delimited. Two cases, involving licensing of hydroelectric projects under the Federal Power Act, dominate this area of law.

Udall v. FPC ${ }^{28}$ involved the licensing of the Pacific Northwest Power Company to construct a hydroelectric power project at High Mountain Sheep on the Snake River. The Supreme Court ordered the case remanded to the FPC because the Commission had failed to explore the alternative of federal development of the site. ${ }^{29}$ In discussing the scope of the issues and the Commission's duty on remand, the Court considered section 10(a) of the Act, which provides that, as a condition to licensing:

[T] he project adopted ... shall be such as in the judgment of the Commission will be best adapted to a comprehensive plan for improving or developing a waterway or waterways for the use or benefit of interstate or foreign commerce, for the improvement and utilization of water-power development, and for other beneficial public uses, including recreational purposes. ....30

Mr. Justice Douglas, writing for the Court, held that the test of whether a license should be issued is not simply whether the project will be beneficial to the licensee and whether the region will be able to use the additional power. The test is whether the project will be in the public interest. This determination requires an exploration of all factors relevant to the public interest, including-in addition to future power demand and supply-alternative sources of power, the public interest in preserving wild rivers and wilderness areas, the preservation of anadromous fish, and the protection of wildlife. ${ }^{31}$ The Court refused to assume that the Federal Power Act "commands the immediate construction of as many projects as possible." 32

The Udall case followed a decision by the Second Circuit Court of Appeals setting aside an FPG license authorizing Consolidated Edi-

28387 U.S. 428 (1967).

29 Section 7(b) of the Federal Power Act, 16 U.S.C. \& 800(b) (1964), provides: "Whenever, in the judgment of the commission, the development of any water resources for public purposes should be undertaken by the United States itself, the commission shall not approve any application for any project affecting such development. . . ."

30 16 U.S.C. § 803(a) (1964). The licensing standard, \& 4(e), I6 U.S.C. § 797(e) (1964), is "necessary or convenient for the development and improvement of navigation and for the development, transmission, and utilization of power across, along, from, or in" any navigable streams or bodies of water, with the proviso that whenever the contemplated development is "desirable and justified in the public interest for the purpose of improving or developing a waterway or waterways for the use or benefit of interstate or foreign commerce," the Commission shall make a finding to that effect.

31387 U.S. at 450 .

32 Id. at 449. 
son of New York to construct a pumped storage hydroelectric plant at Storm King Mountain on the Hudson River. ${ }^{33}$ The court there found that the record "fails markedly to make out a case for the Storm King project on, among other matters, costs, public convenience and necessity, and absence of reasonable alternatives." 34 It held that the Commission has a "specific planning responsibility" under section 10(a) and that the "totality of a project's immediate and long-range effects, and not merely the engineering and navigation aspects, are to be considered in a licensing proceeding." 35 The court ordered the Commission to include as "a basic concern" in the proceedings on remand the preservation of natural beauty and national historic shrines, "keeping in mind that, in our affluent society, the cost of a project is only one of several factors to be considered." 36

The Commission, said the court, could not assume a passive role; it "must see to it that the record is complete"; it "has an affirmative duty to inquire into all relevant facts," including possible alternatives to the proposed project. The court pointed out:

In this case, as in many others, the Commission has claimed to be the representative of the public interest. This role does not permit it to act as an umpire blandly calling balls and strikes for adversaries appearing before it; the right of the public must receive active and affirmative protection at the hands of the Commission. ${ }^{37}$

Taken together, Udall and Scenic Hudson lead to two conclusions relevant here. First, the scope of "public interest" cannot be limited to the interests of the consuming public and the regulated industry. Demand and dollar outlays for the proposed service cannot be controlling. Noneconomic factors, whether natural beauty or wildlife resources, must be included in the balance. Second, the regulatory agency must fill any gaps in the record before making a decision. It must seek to interject issues, even those beyond its regulatory jurisdiction, into the proceeding.

Neither of these conclusions is limited to Federal Power Act proceedings. Courts have required a similarly inclusive construction of

33 Scenic Hudson Preservation Conf. v. FPG, 354 F.2d 608 (2d Cir. 1965), cert. denied, 384 U.S. 941 (1966).

34354 F.2d at $624-25$.

$35 I d$. at 620 . Specifically, the court held that the Commission should have inquired into the cost of running segments of the transmission line underground in this area of "unique beauty." Id. at 623 .

36 Id. at 624 .

37 Id. at 620. On this point see Comment, Of Birds, Bees, and the FPC, 77 YALE L.J. 117 (1967). 
public convenience and necessity under the Natural Gas Act. The Supreme Court has held that a public convenience and necessity determination under that Act "requires the [Federal Power] Commission to evaluate all relevant factors,"38 including conservation of natural gas and air pollution alleviation through increased use of this fuel. ${ }^{39}$ Circuit courts have pointed out that a regulatory agency cannot limit its view of the public interest to the horizons of the private parties to the proceeding ${ }^{40}$ and that it must consider effects on competitive industries in determining public convenience and necessity, ${ }^{41}$ as well as alternatives to an applicant's proposal. ${ }^{22}$ That it has no authority to command a more desirable alternative does not mean that it cannot reject the proposal.43

The Givil Aeronautics Board has not indicated a willingness to follow the lead of the courts in broadly construing the scope of the issues in a certification proceeding. A recent Board order instituting an investigation of the need for, and feasibility of, VTOL, V/STOL, and STOL service between metropolitan areas in the northeast corridor $^{44}$ is indicative of the Board's conception of its role.

The Board declared that the "major problem and principal matter" to be considered in the VTOL Investigation is improvement in the quality of air service in northeast corridor markets, "particularly to meet the needs of the business traveler." It noted that air transportation is slowed because of the difficulty of ground transportation and congestion of existing airports in the corridor. The Board reasoned

38 Atlantic Refining Co. v. Public Serv. Comm'n, 360 U.S. 378, 391 (1959). The licensing standard in the Natural Gas Act, $\S 7$ (e), 15 U.S.C. $\S 717 f(e)$ (1964), reads "is or will be required by the present or future public convenience and necessity."

39 FPC v. Transcontinental Gas Pipe Line Corp., 365 U.S. 1 (1961).

40 Mfichigan Consol. Gas Co. v. FPC, 283 F.2d 204, 226 (D.C. Cir. 1960).

41 City of Pittsburgh v. FPC, 237 F.2d 741 (D.C. Cir. 1956); cf. Virginia Petroleum Jobbers Ass'n v. FPC, 265 F.2d 364 (D.C. Cir. 1959).

42 City of Pittsburgh v. FPC, 237 F.2d 741 (D.C. Cir. 1956).

$43 I d$. at 751 n.28. On the scope of "public interest" under other statutes, see Denver \& R.G.W.R.R. v. United States, 387 U.S. 485, 492 (1967) (The Court has "read terms such as 'public interest' broadly, to require consideration of all important consequences."); Schaffer Transp. Co. v. United States, 355 U.S. 83 (1957); ICG v. Railway Labor Executives Ass'n, 315 U.S. 373 (1942); United States v. Lowden, 308 U.S. 225 (1939); New York Cent. Sec. Corp. v. United States, 287 U.S. 12 (1932); Western Air Lines, Inc. v. CAB, 194 F.2d 211 (9th Cir. 1952).

44 Northeast Corridor VTOL Investigation, CAB Order No. E-25779 (Oct. 4, 1967) (order instituting Docket No. 19078). The "metropolitan areas" to be considered are Boston, Hartford, Providence, New York/Newark, Philadelphia/Wilmington/Trenton, Baltimore, and Washington. The Board defines VTOL, the "principal focus of the investigation," as vertical take-off and landing equipment; V/STOL as "a type of aircraft which has vertical take-off and landing capability, but is also designed to benefit from short take-off and landing runs"; and STOL as equipment capable of short take-off and landing runs. 
that the speed advantages of air transportation could be maximized by making a convenient service available to the business traveler from the center of one city to the center of another, or even (since "it may be that the business traveler resides in a suburban point") from the suburbs to his business destination in the center of the other city. VTOL service could reduce congestion at existing airports, since a significant portion of flights now operating from these airports in the corridor are "primarily for the benefit of, and in response to, business travel." Moving this travel from existing airports would improve their capability to handle flights to and from points outside the corridor. ${ }^{45}$

The Board found statutory authority for its investigation, despite the lack of operational aircraft and city and suburban landing points at the present time, in its obligation to "promote and develop air transportation." To permit coordination of urban renewal programs with the establishment of appropriate landing sites-coordination which the Board believes "may be an important factor in orderly redevelopment embracing transportation as a key element" 48 - the Department of Housing and Urban Development is made a party to the proceeding. ${ }^{47}$

Noise went unmentioned in the Board's order, although it is a major problem with vertical and short take-off and landing aircraft. The FAA has admitted that the "potential of V/STOL aircraft for close-in operation is their selling feature, but the noise they produce could be their ruin." 48 It has warned that future helicopters and V/STOL craft will "have to be quieter than aircraft in operation today," and that landing sites "should be convenient, but somewhat displaced from the heart of the city" in industrial, rather than business or residential, areas. ${ }^{49}$

Transportation alternatives are also germane to northeast corridor VTOL service, particularly because the federal government is actively

45 Consequently, existing airports are excluded from consideration as possible landing points for the new service. In addition, the Board will consider amendment of certificates of carriers presently flying northeast corridor routes to restrict their service to existing airports.

46 For one conception of how this "key element" might look in a downtown area, see N.Y. Times, Oct. 7, 1967, at 37, col. 1 .

47 In addition to its urban renewal authority, HUD has research and coordination responsibility in the aircraft noise field. See notes 25 supra and 64 infra.

48 Federal Aviation Admin., Aircraft Dev, Serv., First Annual R/D Report to Industry, V/STOL Air Transportation 2 (mimeo. 1967), reprinted in part in 1 CCF CLEAN ATR NEws No. 30, at 5 (Aug. 15, 1967).

$49 \mathrm{Id}$. at 5. The FAA suggests locations "over railroad yards and highways and along highways." Id. 
involved in research and development and demonstration programs for high-speed ground transportation in the corridor. ${ }^{50}$

The order instituting the VTOL investigation indicates the Board's reluctance to expand the scope of already protracted proceedings under section 401 . One can hardly expect an agency which considers the promotion of air transportation one of its primary duties ${ }^{51}$ to view proposals for new service skeptically because air transportation involves detriments as well as benefits. The Civil Aeronautics Board is not the agency to which overall transportation planning authority would be given if the regulatory apparatus were rationally organized. Nor, perhaps, should transportation planning be conducted in administrative proceedings that result in obscuring basic public interest questions about the need for service and possible alternatives in a mass of evidence about which private applicant is most qualified to perform the service. But political exigencies have produced such a system of transportation decision-making. The question is not whether this is the optimum arrangement, but how the regulatory agency might take into account all the relevant issues in making its determinations..$^{52}$

The relative maturity of the air transportation industry underscores the desirability of the Board's adopting a different outlook now from that it assumed when the industry was in economic difficulty and required active governmental assistance. It is no longer sufficient, if it ever was, for the Board to consider promotion of air transportation and the establishment of orderly competition within the industry as its major functions. The noise problem, as well as airport congestion and ground transportation delays, compel a broader view.

In the past, aside from diversion from competitive air carriers, the

50 The High Speed Ground Transportation Act of 1965, 49 U.S.C. \$§ 1631-42 (Supp. 1966), authorizes these activities to determine the contribution high speed ground transportation could make to more efficient and economical intercity transportation systems. In support of this legislation, the House Interstate and Foreign Commerce Committee argued that the demonstrations are "essential before commitments are made to major public investment for transportation in the northeast corridor or other corridors." H.R. REP. No. 845, 89th Cong., lst Sess. 6 (1965).

51 "[T]his agency is charged with the duty of promoting air transportation. Normally, the Board should not, consistent with this mandate, take action which would diminish or interfere with the accessibility and use of air transportation by the public." Eastern North Carolina Airline Serv. Airport Investigation, CAB Order No. E-21051 (July 10, 1964).

62 See generally Reich, The Law of the Planned Society, 75 YaLe L.J. 1227 (1966). "We have to face the fact ... that short of creating a wholly new agency with authority to act on environmental issues, we have no alternative but to work with those existing organizations which have, so far, failed, and, worse, shown little or no interest in succeeding. . . . [ ] $f_{f}$ these existing agencies won't see the challenge, new legislation to make them do so would be difficult to get enacted and even more difficult to get them to implement effectively." Representative Richard L. Ottinger, in 113 CoNG. REc. A5057 (daily ed. Oct. 12, 1967). 
Board has identified and considered only one cost of air transportation -government subsidies-with any degree of regularity. Subsidies are rarely an issue in service to major metropolitan areas; only local service has been subsidized in recent years. ${ }^{53}$ The Board has occasionally pointed to problems of airport congestion, ${ }^{54}$ and is beginning to do so more often; ${ }^{55}$ it has found safety relevant in some proceedings. ${ }^{56}$

But the Board has utterly disregarded environmental impact, a major external cost of air transportation. ${ }^{57}$ There is presently no method of placing a dollar cost on environmental impact, particularly the impact of additional air transportation on an area already plagued by overflights. No systems analysis, no cost-benefit approach has been able to account for this kind of cost. ${ }^{58}$ This should not be taken, however, as an excuse to neglect it. ${ }^{59}$

Not all aircraft produce an equal amount of noise; moreover, the offensiveness of aircraft noise varies with such factors as the frequency of flights. ${ }^{60}$ Assuming equally noisy aircraft, the impact of the first daily overflight introduced into a residential area may be less than

531966 CAB ANNUAL RePORT 35.

54 New York-Florida Case, 24 C.A.B. 94, 111 (1956); Middle Atlantic Area Case, 9 G.A.B. 131, 180 (1948); Air Commuting, Inc., New York City Area, 8 C.A.B. 1 (1947).

55 See Service to White Plains, N.Y., CAB Order No. E-25913 (Nov. 2, 1967) (order instituting Docket No. 19201), and Washington-Baltimore Airport Investigation, $\mathrm{CAB}$ Order No. E-25319 (June 20, 1967) (order instituting Docket No. 18712), as well as Northeast Corridor VTOL Investigation, CAB Order No. E-19078 (Oct. 4, 1967), for recent expressions of Board concern.

56 E.g., Spearfish Suspension Case, 18 C.A.B. 657 (1954); All American Aviation, PickUp, Delivery Service, 2 G.A.B. 133, 151-52 (1940).

57 It has also refused to consider the impact of authorizing additional air service on railroads, holding that it will not "retard air transportation for the railroads' protection and benefit." New York-Florida Case, 24 C.A.B. 94, 119-20 (1956).

58 To the extent that noise in residential areas results in decreased property values, a numerical estimate of the cost is theoretically possible, But it is hardly practicable to isolate this factor from others affecting property values. Economists are just beginning to attempt to assess the magnitude of property value loss associated with environmental pollution. See the estimates of loss from air pollution in Ridker \& Henning, The Determinants of Residential Property Values with Special Reference to Air Pollution, 49 REv. EcoN. \& STAT. 246 (1967). Moreover, this loss of value is not the only cost of environmental pollution.

59 As the District of Columbia Gircuit Court of Appeals said in affirming CAB issuance of a certificate: "The conclusion to be reached is not a figure, and the factors from which the conclusion must be fashioned under the statute are not dollar amounts. In large part they are imponderables. . . There is no formula for combining these elements into a conclusion." United Air Lines, Inc. v. CAB, 155 F.2d 169, 175 (D.C. Cir. 1946). What is involved is a choice between courses of action; it can validly be made without precise predictions of the results of each course. Id.

60 Other factors related to the offensiveness of aircraft noise have been identified, including time of day of flights, ambient noise levels in the area, atmospheric conditions, and nonquantifiable factors such as the economic importance of air transportation to the community, the degree of change associated with the introduction of new operations, and the reaction of responsible authorities. BOLT, BERANER \& NEWMAN, INC., LAND USE Planning Rziating to Aircraft Noise (1964). 
that of the two hundredth. And the marginal impact of the two hundredth is not great. It could be argued, therefore, that it makes no sense to require Board consideration of the environmental impact of either the first air service introduced over an area (assuming a minimal number of flights are contemplated) or additional service once a certain, as yet indeterminate, level of service has been reached. ${ }^{61}$ By this view, carried to its logical conclusion, environmental impact can never be a decisive factor in certification proceedings.

An obvious exception to this argument is the authorization of a new type of air transportation that would introduce a significant number of offensive overflights in an area previously untroubled by aircraft noise. Moreover, the argument that the marginal environmental impact of additional service is the relevant factor is not necessarily valid. It is akin to saying that aesthetic considerations in the Storm King case ${ }^{62}$ deserve only scant attention because most of the natural beauty of the Hudson has already been destroyed. ${ }^{63}$ The reasoning that would lead a regulatory agency to say that, having allowed the creation of a situation damaging residential areas, it need not give much attention to any worsening of the situation resulting from its future decisions, leaves something to be desired.

Environmental impact should be measured with reference to alternative transportation schemes. Its assessment depends on an estimation of the incidence of environmental impact from particular service. For noise, proposed routing, altitudes, schedules, equipment, and landing sites are all significant. With information on these variables and data on noise emission of aircraft, it would be possible to estimate the number of persons, enterprises, and parks, historic, and scenic areas that would be inconvenienced by the proposed service. The extent of this inconvenience, in the absence of established noise standards, is more difficult to judge. Such standards as do exist, imperfect as they are, could be used to determine whether the number for whom the in-

61 An example of this kind of reasoning is found in the hearing examiner's denial of citizens' groups intervention in the Washington/Baltimore Helicopter Serv. Investigation. The examiner found that the impact of new helicopter service on existing noise conditions primarily stemming from the operations of Washington National Airport "will constitute a negligible addition to the principal sources of noise." CAB Order No. E-25435 (July 19, 1967) (issued under delegated authority; aff'd by the Board in Order No. E-25704, discussed in note 9 supra and accompanying text).

62 From which arose Scenic Hudson Preservation Conf. v. FPG, 354 F.2d 608 (2d Cir. 1965).

63 Economically, this conclusion might be perfectly justified. See Coase, The Problem of Social Cost, 3 J. LAw \& EcoN. 1 (1960). But the decision of a regulatory agency, while guided by economics, is also a political decision. The whole thrust of Scenic Hudson and Udall is that the nation is willing to sacrifice current production to preserve natural amenities and that regulatory agencies cannot disregard this national commitment to economic suboptimization. 
convenience is serious is great enough to outweigh the public need for additional air service, particularly where feasible transportation alternatives exist.

In the introduction of totally new service, such as VTOL in the northeast corridor, there is an additional consideration. Not only will the establishment of the service have an impact on people on the ground, its inauguration will require the construction of new airports. Clearly, the costs (as well as the benefits) associated with their construction are relevant to a determination whether the service is required for the public convenience and necessity. Not all of these costs are direct. Of equal, perhaps even greater, importance is the effect the establishment of the airport will have on surrounding land use. Location of VTOL airports in urban renewal areas, as the Board is considering, would impose strictures on development of the remainder of the renewal area to assure compatibility. ${ }^{64}$ The significance of this constraint on inner city development will vary, of course, from city to city.

There may well be instances in which environmental impact, in conjunction with other factors, will tip the balance against the authorization of any new air service over a particular route. In other cases, however, any findings as to public inconvenience caused by noise and other deleterious byproducts of air transportation will indicate, not that the application should be totally rejected, but that the service authorized should be limited in some manner to minimize its intrusiveness while not destroying its usefulness to the traveling public. In these circumstances, the Board should carefully define the authorized service in the certificate.

A certificate issued under section 401 specifies the terminal and intermediate points between which the carrier is authorized to engage in air transportation and the service to be rendered. The Board has the authority to attach "such reasonable terms, conditions, and limitations as the public interest may require" to the exercise of the privileges granted by the certificate. ${ }^{65}$ The Board has indicated that the question of what operating restrictions or limitations should be imposed is implicit in every route proceeding. ${ }^{60}$ Under the Act, however, no term, condition, or limitation may:

64 See President's Memorandum to Heads of Departments and Agencies, Aircraft Noise and Land Use Near Airports, 3 WeEkLy Comprl. Pres. Docs. 527 (March 27, 1967). The President directed all executive departments and agencies "to take into explicit and due account aircraft noise whenever it is relevant to any of their programs or to action in which they participate" and to cooperate with HUD, the department "most concerned with compatible land use in the vicinity of airports," as well as DOT on this problem.

65 Federal Aviation Act of 1958, § 401(e)(1), 49 U.S.C. § 1371(e)(1) (1964).

68 See Southeastern Area Local-Serv. Case, 30 C.A.B. 1318, 1445 (1960) (supplemental opinion and order on reconsideration). 
restrict the right of an air carrier to add to or change schedules, equipment, accommodations, and facilities for performing the authorized transportation and service as the development of the business and the demands of the public shall require. ${ }^{67}$

Despite this prohibition, the Board has considerable power to define and limit the authorized service in light of the requirements of the public convenience and necessity. ${ }^{68}$

It is settled that the Board may designate an airport as a service point if the public interest requires. ${ }^{69}$ The air transportation regulated under the Federal Aviation Act is that between places, not necessarily between cities. ${ }^{70}$ By this reasoning, it would seem that the Board could delimit the area within which an airport for new service (such as VTOL) would have to be located. The Board has asserted its authority to define the scope of proceedings in such a manner as to limit the possible location of an airport. ${ }^{71}$ In the Northeast Corridor VTOL Investigation, the Board will consider "landing sites in the respective metropolitan areas, excluding the existing air carrier airports serving the named cities." 22 On an evidentiary record, the Board might define the landing site in much more specific terms. For example, to minimize the environmental impact of the service for which a certificate is granted, the Board might authorize service to a point within a given radius of the center of the city, but not less than a given distance from any residential, historic, or recreational area. Alternatively, it might specify the type of land use zone within which the service point must be located. ${ }^{73}$

67 Federal Aviation Act of 1958, \& 401(e)(4), 49 U.S.C. \& 1371(e)(4) (1964).

68 Since the "public interest" as defined in the Act, $\S 102,49$ U.S.C. $\S 1302$ (1964), is coextensive with the "public convenience and necessity," the Board may impose limitations by reference to the same criteria.

69 City of Dallas v. CAB, 221 F.2d 501 (D.C. Cir. 1954), cert. denied, 348 U.S. 914 (1955); accord, Airport Comm'n of Forsyth County v. CAB, 300 F.2d 185 (4th Cir. 1962).

70 City of Dallas v. CAB, 221 F.2d 501, 504 (D.C. Cir. 1954); see Federal Aviation Act of 1958, § 101(21), 49 U.S.C. \& 1301(21) (1964).

71 It has also considered the location of existing airports as a relevant factor in public convenience and necessity determinations. E.g., New Castle County Airport Comm'n v. CAB, 371 F.2d 733 (D.C. Cir. 1966); Outagamie County v. CAB, 355 F.2d 900 (7th Cir. 1966); City of Lawrence v. CAB, 343 F.2d 583 (1st Cir. 1965).

72 CAB Order No. E-25779 (Oct. 4, 1967) (footnote omitted). The Board does leave open the precise definition of "metropolitan area," but it clearly intends some areal limitation of landing sites. See also Washington, D.C. Helicopter Serv. Case, 38 C.A.B. 823, 884 (1963) (proposed location for heliport a factor in denial of certificate).

73 Obviously, as a practical matter, the Board would not want to designate a service point with such specificity as to make the inauguration of the service-for which the Board has found a public need outweighing its drawbacks-contingent on construction of an airport at a precise location. It is for this reason that the suggestion made here is for designation of land use zones or limitations on distances from downtown and residential areas. 
The Board has also recognized its authority to limit the type of equipment a carrier may use, despite the prohibition in section 401 (e)(4). In granting a certificate for service by rotary wing aircraft in Los Angeles Airways Renewal Case, the Board held that:

[T] he authority to specify the service to be rendered necessarily includes the power to define in precise terms the kind of service to be rendered in such a way that the authorization will conform to and spell out the service which is found to be required by the public convenience and necessity, and in such a way that the authorization will not permit greater service than that found to be required by the needs of the public. ${ }^{74}$

The Board has designated equipment type in helicopter service cases to prevent competition with local service air carriers. ${ }^{75}$ Under the holding in Los Angeles Airways, however, it may specify equipment type for any reason consonant with the public convenience and necessity. Its authority to specify the service authorized extends to other factors, as well. It could define "in precise terms" not only the type of equipment to be used, but also airways to be utilized and other operating criteria designed to keep environmental impact below a reasonable standard consistent with the public convenience and necessity.

Simply by calling a restriction a specification of the kind of service required by the public convenience and necessity, the Board cannot circumvent the prohibition of section 401(e)(4). The "mere form of the Board's order would not be controlling, if its substance were in conflict with the terms of the Act." ${ }^{16}$ For this reason, the Board's authority to define service to be offered may not extend to a specification of the number of flights per day between service points. ${ }^{77}$ But, just as the Board has undoubted authority to specify seasonal operations, ${ }^{78}$ it presumably could limit service to those hours of the day when environmental impact is minimized.

In these areas, municipal airport authorities and the FAA have regulatory power, as the Board has indicated.79 It may be reasonable, in

74 Los Angeles Airways Renewal Case, 27 C.A.B. 36, 40 (1958). The Board found support for its specification of equipment type in Crescent Express Lines, Inc. v. United States, 320 U.S. 401 (1943).

75 See New York Airways Renewal Case, 30 C.A.B. 898, 902-03 (1960).

78 City of Dallas v. CAB, 221 F.2d 501, 503-04 (D.C. Cir. 1954).

77 United Air Lines, Inc. v. CAB, 278 F.2d 446 (D.C. Cir.), vacated, 364 U.S. 297 (1960).

78 Service in the Rocky Mtn. States Area, 6 C.A.B. 695, 739 (1946).

79 Washington/Baltimore Helicopter Serv. Investigation, $\mathrm{GAB}$ Order No. E-25704 (Sept. 19, 1967). 
particular proceedings, for the Board to leave the regulation of environmental impact to these agencies. ${ }^{80}$ To the extent that environmental impact is relevant to public convenience and necessity, however, the Board itself might consider specification of service in terms that will minimize this impact. While such specification would restrict the FAA in its regulation of airspace use and the local airport authority in its choice of site or runway patterns, the restriction is different only in degree and not in kind from that stemming from any certificate of public convenience and necessity. Legally, there would appear to be no difficulty, since neither the FAA nor the airport authority need take the further action necessary to allow the carrier to implement the authorized service. ${ }^{81}$ Participation by the Department of Transportation and municipal authorities in a proceeding will, of course, aid the Board in framing its certificate in realistic terms. ${ }^{82}$

\section{II}

Most air carrier operations with significant environmental impact, with the exception of V/STOL service, have already been authorized by the Board.83 New subsonic jets and the supersonic transport will probably be introduced on existing routes, as new equipment has been in the past. Although the Board could utilize its statutory authority to amend or modify outstanding certificates to redefine authorized service in order to minimize the environmental impact of new equipment (or other changes in conditions), ${ }^{84}$ there is little likelihood of its doing so. ${ }^{85}$ Effective regulation requires a more direct approach.

80 Cf. North Central Airlines, Inc. Renewal of Temporary Intermediate Points, 32 C.A.B. 1205, 1222 (1961) (safety of an aixport approved as safe by the proper governmental authorities not at issue).

81 Federal Aviation Act of 1958, § 401(i), 49 U.S.C. \& 1371(i) (1964) provides that: "No certificate shall confer any proprietary, property, or exclusive right in the use of any airspace, Federal airway, landing area or air-navigation facility." Implementation of a certificate of public convenience and necessity requires an air carrier operating certificate from the FAA and arrangement for a landing area through lease from an airport operator or other means.

82 The view of the FAA is entitled to great weight. See Spearfish Suspension Case, 18 C.A.B. 657, 664 (1954).

83 Some under "grandfather" certificates, issued to carriers operating in 1938 when the Civil Aeronautics Act became law, without any requirement of a showing of public convenience and necessity. Civil Aeronautics Act of 1938, ch. 601, § 401(e), 52 Stat. 988.

84 Under the Federal Aviation Act of 1958, § 401(g), 49 U.S.C. \& 1371(g) (1964), the Board may "alter, amend, modify, or suspend any ... certificate, in whole or in part, if the public convenience and necessity so require." But see CAB v. Delta Airlines, Inc., 367 U.S. 316 (1961); Ryan, The Revocation of an Airline Certificate of Public Convenience and Necessity, 15 J. ARr L. \& CoM. 377 (1948).

85 Indeed, a large proportion of the Board's regulatory activity under section 401 in recent years has been directed at realigning routes to conform to the operating require- 
That direct regulation might come from the Federal Aviation Administration, and to some extent it has. Under section 307(c) of the Federal Aviation Act, the Administrator of the FAA prescribes air traffic rules governing aircraft flight in navigable airspace

for the navigation, protection, and identification of aircraft, for the protection of persons and property on the ground, and for the efficient utilization of the navigable airspace. ${ }^{86}$

The inclusion of "the protection of persons and property on the ground" among the purposes of air traffic rules is construed by the FAA as authorizing noise abatement rules. ${ }^{87}$ Existing noise abatement procedures were promulgated under this provision. While there has been debate about the efficacy of these rules, ${ }^{88}$ the FAA cannot be faulted for neglecting noise in designing flight procedures. It has repeatedly stated that it considers noise second only to safety as a matter of regulatory concern.

But these noise abatement rules are applied to aircraft, engines, and equipment for which type, production, and airworthiness certificates are issued without regard to their noise characteristics, ${ }^{89}$ flown by air carriers under operating certificates issued with reference to safety criteria alone. ${ }^{90}$

The Administrator claims that he has no statutory authority to develop and apply noise standards in these certification proceedings. This contention is open to question. Arguably, the Administrator could regulate aircraft noise directly, under the present statute, by refusing to certify aircraft that do not meet noise standards and by

ments and economies of new equipment, particularly short-range jets, at the request of carriers. See generally 1966 CAB ANNUAL REPORT 1-6.

8649 U.S.C. $\$ 1348$ (c) (1964).

87 See House 1968 NASA Authorization Hearings, supra note 2, pt. 4, at 374. The in. clusion of this language may not have been an attempt by Congress to provide for noise abatement rules. The history of air traffic rules-beginning with the Air Commerce Act of 1926-indicates that the primary concern with regard to those on the ground was the danger of crashes in heavily populated areas and of objects falling from aircraft in flight. U.S. Cong., Office of legislative Counser, Civit Afronautics: Iegislative History of AIR Commerce ACT of 1926 (1928); D. WhitNah, SAFER SKyways: Federal Control of AviAtion, 1926-1966 (1966). The present language was first used in the Federal Aviation Act of 1958 , but even at that late date there was no indication of any additional congressional concern with noise.

88 There have been claims that they jeopardize safety and that they are less effective than alternative flight procedures in abating noise. See H.R. Rep. No. 36, 88th Cong., Ist Sess. 21 (1963).

89 Federal Aviation Act of 1958, § 603, 49 U.S.C. § 1423 (1964). Certification requires compliance with minimum standards prescribed by the Administrator "to promote safety of flight." Id. § 601(a), 49 U.S.C. \& I421(a) (1964).

90 Id. $\S 604,49$ U.S.C. $\S 1424$ (1964). Air carrier operating certificates include conditions "reasonably necessary to assure safety in air transportation." Id. 
placing conditions on air carrier operating authority. ${ }^{91}$ And the Department of Transportation has admitted that the Administrator could regulate noise characteristics of aircraft indirectly, by establishing flight rules under section 307 (c) stringent enough to prohibit the use of the noisiest aircraft without modifications to quiet them. ${ }^{92}$

Neither course has been adopted. Instead, the FAA has sought amendment to the Federal Aviation Act to give it authority to set noise and sonic boom standards and apply them in title VI certification proceedings. ${ }^{93}$ Attempts to add this type of provision to the Department of Transportation Act failed on the House floor in $1966 .{ }^{94} \mathrm{~A}$

91 In performing his duties, the Administrator is bound by a definition of the "public interest" similar in form to that prescribed for the Board. The preamble to section 103, in its codified form, reads:

In the exercise and performance of his powers and duties under this chapter

the Administrator shall consider the following, among other things, as being in

the public interest

and is followed by five criteria relating primarily to safety, promotion and development of air commerce, and control of the use of navigable airspace for the safety and efficiency of both civil and military aircraft. Id. § 103, 49 U.S.C. $\S 1303$ (1964). A "public interest" standard is specifically prescribed in a number of sections of the Act. $I d$. $\$ \S 307$ (a), (e), $505,601(\mathrm{c}), 607,610(\mathrm{~b}), 1104,49$ U.S.C. $\$ \$ 1348(\mathrm{a}),(\mathrm{e}), 1405,1421(\mathrm{c}), 1427,1430(\mathrm{~b}), 1504$ (1964). Cf. id. $\$ \S 305,306,49$ U.S.C. $\S \S 1346,1347$ (1964), which prescribe policy for the Administrator and would be duplicative of section 103, at least in part, if that section were construed as a declaration of policy binding the Administrator.

The Department of Transportation Act, however, broadens the applicability of section 103. In transferring the powers and duties of the Administrator of the Federal Aviation Agency and requiring their delegation to the Administrator of the Federal Aviation Administration within the Department, the Act provides that, in exercising his functions, powers, and duties pertaining to aviation safety, the Administrator "shall be guided by the declaration of policy in section 103 of the Federal Aviation Act." Department of Transportation Act \& 6(c)(I), 49 U.S.C. \& 1655(c)(1) (Supp. 1966). Arguably, therefore, the limitation of the sections dealing with equipment and air carrier operating certificates to safety considerations may no longer be effective. The FAA's regulatory authority is now coextensive with the policy of section 103. With reference to the similarly worded preamble of section 102, the Department of Transportation has argued that it requires "only that the Board consider the six enumerated categories 'among other things,' and does not limit the Board's duty to consider other public interest factors." DOT Helicopter Answer, supra note 10, at 2. "The public interest in safely attainable quiet is obvious." American Airlines, Inc. v. Town of Hempstead, 272 F. Supp. 226, 234 (E.D.N.Y. 1967) (dictum). Just as with the Board, two of the criteria-subsections (a) and (c)-might be interpreted to include noise among the relevant public interest factors.

Militating against this construction is the FAA's position that new legislative authority is needed. Moreover, the House debate on adding noise abatement regulatory authority to the Department of Transportation Act proceeded on the unspoken premise that the Federal Aviation Act provided no authority of this sort. 112 Cong. REc. H19517-21, H19523 (daily ed. Aug. 24, 1966); id. at H20346-55 (daily ed. Aug. 30, 1966). See also H.R. REP. No. 36, 88th Cong., 1st Sess. 22 (1963).

92 House 1968 NASA Authorization Hearings, supra note 2, pt. 4, at 507. The Department argues, however: "This course of action would be less direct and less likely to achieve the design objectives we have in mind." Id.

93 See supra note 12.

o4 See supra note 91 . 
House committee held hearings, but no bill was reported out during the 89th Congress. ${ }^{95}$ Prospects for passage in the 90th Congress are better although the legislation has been moving at a dilatory pace. ${ }^{96}$

Its enactment, or the assertion of regulatory authority by the FAA without new legislation, may not be an unmixed blessing. The Federal Aircraft Noise Committee, which includes the FAA, has argued that adoption of the legislation may "affect the liability of the Federal Government for ... property losses" caused by aircraft noise because it might be construed to preclude inverse condemnation recoveries against airport operators:

Assume the enactment and implementation of the legislation, so that a given aircraft is certificated to operate at 100 PNdB [perceived noise decibels]. If such aircraft are so operated, in any litigation alleging a taking by reason of 100 PNdB over-flights, a court could conclude that the cause of the taking was Federal certification rather than inadequate acquisition by the airport.

This does not mean, the committee continues, that the federal government should assume liability; whether or not it should is a "problem [to] be answered on the basis of an objective cost/benefit analysis." But, to the extent that the federal government exercises its right to regulate aircraft noise, "the answer may be supplied by a court finding that the airport operator is without fault" because of the federal certification. ${ }^{97}$

Federal liability might follow from such a holding. A more likely result, however, is that the difficulty of proof of a taking in the constitutional sense $\mathrm{e}^{98}$ would be compounded. If, as in the committee's hypothetical, the aircraft were operating within the noise maxima prescribed by the FAA (under legislation which empowers the Secretary of Transportation "to prescribe and amend such rules and regulations as he may find necessary to provide for the control and abatement of aircraft noise and sonic boom"), the plaintiffs might have a difficult time showing that they had been damaged or that the damage was not damnum absque injuria. Even assuming federal liability under the fifth amendment, that liability may be more limited than that of public airport authorities, especially those in states whose constitutions

95 The legislation was introduced in July 1966; hearings were held on October 12.

96 S. 707 and H.R. 3400 were introduced early in the first session; House hearings were held in mid-November 1967.

97 House 1968 NASA Authorization Hearings, supra note 2, pt. 4, at 375.

98 See Griggs v. Allegheny County, 369 U.S. 84 (1962); United States v. Causby, 328 U.S. 256 (1946). 
provide for compensation for damaging as well as taking. ${ }^{99}$ One effect of FAA regulation, therefore, might be the restriction of private remedies. ${ }^{100}$

Another might be the preclusion of local regulation of aircraft noise. Two ordinances seeking to regulate aircraft noise have been challenged in federal courts. One simply banned all overflights below $1000 \mathrm{feet}^{101}$ the other, in form a general noise abatement ordinance, was found to have the effect of banning overflights. ${ }^{102}$ Both were held unconstitutional, as applied to aircraft, under the commerce clause. ${ }^{103}$ It is doubtful that other ordinances could meet the constitutional test prescribed in these cases, but, absent express federal regulation of aircraft noise, some might. ${ }^{104}$ If Congress explicitly provides for noise

99 See Spater, Noise and the Law, 63 MICH. L. REv. 1373, 1381-1410 (1965); Stoebuck, Condemnation by Nuisance: The Airport Cases in Retrospect and Prospect, 71 Dick. L. REv. 207 (1967); Tondel, Noise Litigation at Public Airports, 32 J. AIR L. \& CoM. 387, 398-407 (1966). Tondel points out that federal fifth amendment "taking" is not always more narrowly construed than "taking" under state constitutions. But twenty-six states have constitutional provisions requiring compensation for a damaging or injury, as well as a taking. Id. at 404 n.93. Compare Thornburg v. Port of Portland, 233 Ore. 178, 376 P.2d 100 (1962), 244 Ore. 69, 415 P.2d 750 (1966), Martin v. Port of Seattle, 63 Wash. 2d 309, 391 P.2d 540 (1964), cert. denied, 379 U.S. 989 (1965), and Ackerman v. Port of Seattle, 55 Wash. 2d 400, 348 P.2d 664 (1960), with Batten v. United States, 306 F.2d 580 (10th Cir. 1962), cert. denied, 371 U.S. 955 (1963). Accord, Neher v. United States, 265 F. Supp. 210 (D. Minn. 1967); Bennett v. United States, 266 F. Supp. 627 (W.D. Okla. 1965); Bellamy v. United States, 235 F. Supp. 139 (E.D.S.C. 1964); Avery v. United States, 330 F.2d 640 (Ct. Cl. 1964).

100 Contrast the recent suggestion that provision should be made for treble damages for injury from aircraft noise. Parkhurst, Noise, Jets, and the Sonic Boom, reprinted in 113 CoNG. Rec. H14550, HI4552 (daily ed. Nov. 3, 1967).

101 Allegheny Airlines, Inc. v. Village of Cedarhurst, 132 F. Supp. 871 (E.D.N.Y. 1955), aff'd, 238 F.2d 812 (2d Cir. 1956).

102 Amcrican Airlines, Inc. v. Town of Hempstead, 272 F. Supp. 226 (E.D.N.Y. 1967).

103 Section 104 of the Federal Aviation Act, 49 U.S.C. § 1304 (1964), and a comparable section of the prior Civil Aeronautics Act, declare a public right of freedom of transit through navigable airspace, including (under the current provision) the space needed to insure safety in take-off and landing. See id. § 101(24), 49 U.S.C. § 1301(24) (1964).

104 For example, legislation requiring that aircraft flying over a municipality use dispersed flight paths rather than a single noise corridor might be both feasible and desirable in some circumstances. Certainly, if a community adopted an ordinance at variance with, but less restrictive than, FAA-established flight procedures, the burden on those challenging the ordinance to show that it interferes with freedom of transit in navigable airspace would be more difficult to meet than in the Hempstead or Cedarhurst cases. One instance of the noise corridor situation, though not one amenable to local regulation, is the use of the Potomac River by jet flights in and out of Washington National Airport. See U.S. Dep't of the Intertor, Potomac Planning Task Force, The

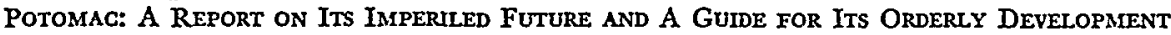
76 (1967). Another type of regulation, imposed by airport authorities as lessors of airport facilities, establishing preferential runway patterns and limiting hours of operation may be constitutional under present federal regulation, but not if Congress expressly provides for noise regulation under title VI. Cf. Port of N.Y. Authority v. Eastern Air Lines, Inc., 
regulation under title VI, the presumption of unconstitutionality of local regulation would be difficult to surmount.

A single regulatory scheme, under federal auspices, is clearly desirable. The national interest in having an air transportation system transcends any local interest of the communities near airports or under flight paths or sonic boom corridors. But the local interest-or at least the aggregate of local interests throughout the nation-should be reflected in the regulation of air transportation. The performance of the FAA has led some observers to doubt the wisdom of giving regulatory authority over aircraft noise to an agency strongly committed to the development and promotion of aviation. One commentator has said that the FAA's " 'regulations' mark it as an arm of the jet industry." 105 Bo Lundberg, a persistent critic of the SST, cites the

fundamental humanitarian principle that the limits for acceptable detrimental side effects to technological developments must not be decided upon by the party who has an economic or other interest in the development. ... "Whether or not a noise is acceptable, must under no circumstances be determined by the party who produces the noise."106

The FAA attempts to keep separate its SST development activities and the certification of the aircraft. General William F. McKee, FAA Administrator, has said that the agency will not certify the SST (or the French-British Concorde) unless it meets safety standards. ${ }^{107}$ Nonetheless, it may not be totally amiss to question the objectivity with which sonic boom certification standards would be developed under the pending legislation in view of the FAA's commitment to the SST. 108

While the conflict is not as obvious, the pressures on the FAA to

259 F. Supp. 745 (E.D.N.Y. 1966). On the constitutionality of the exercise of the local police power in the face of congressional regulation, see Huron Portland Cement Co. v. City of Detroit, 362 U.S. 440 (1960); H.R. REP. No. 36, 88th Cong., 1st Sess. 22-24 (1963); Note, Airplane Noise: Problem in Tort Law and Federalism, 74 HARv. L. REv. 1581 (1961).

105 Parkhurst, supra note 100, at H14561.

106 Senate 1968 DOT Appropriations Fearings, supra note 3, at 567. The statement quoted by Lundberg is by Dr. Professor G. Lehmann, Director of the Max Planck-Institut fur Arbeitsphysiologie, Dortmund, Germany.

107 Id. at 413.

108 In the design competition for the SST, the FAA established its objectives for sonic boom intensity as 2.5 p.s.f. (pounds per square foot) during acceleration, 1.5 p.s.f. during cruise for the overseas version, and 2 p.s.f. during acceleration, 1.5 p.s.f. during cruise for the domestic, overland version. The predicted overpressures for the accepted design presently in the prototype stage, on a coast-to-coast flight, are 1.98 p.s.f. during acceleration, 1.72 p.s.f. at the beginning and 1.55 at the end of cruise. House 1968 DOT Appropriations Hearings, supra note 3 , at 316-17, 313 . 
adopt relatively lax noise standards for subsonic jets and other aircraft will also be great. It has already circulated tentative noise criteria to members of the aircraft industry and, in anticipation of the legislation, is working with them to develop its certification program. ${ }^{109}$ The present thinking within the FAA is that acceptable standards would provide for a noise level of $106 \mathrm{PNdB}$ three miles from the airport. ${ }^{110}$ Whether this is an appropriate standard is open to debate; NASA sets 100 PNdB as the level at which "a noise problem exists with people."111

The problem of aircraft noise, insofar as it is amenable to regulation, is not necessarily solved, therefore, by authorizing the FAA to establish standards. ${ }^{112}$ The need is for regulation by a more impartial agency, better able to balance the needs of air transportation with those of people on the ground. ${ }^{113}$

It is difficult to avoid the conclusion that the effect of the enactment of the pending legislation would be official sanction of the status quo, at least until significant technological developments (such as quieter jet engines) are considered economically feasible by the FAA. The federal regulatory effort seems aimed at assuring that the situation gets no worse, although as air transportation continues to expand there are bound to be more airport neighbors complaining about more overflights. ${ }^{114}$ This will be particularly true as federal research and development efforts lead to introduction of V/STOL and SST craft.

109 House 1968 NASA Authorization Hearings, supra note 2, pt. 4, at 367. The majority of industry members who responded to the proposal supported, in principle, the need for noise certification standards.

110 Id. at 454 (testimony of David D. Thomas, Deputy Administrator of the FAA). The Boeing 747 , the large capacity aircraft now being built, would meet these standards. $I d$. at 446. The 747's predicted noise characteristics are "comparable, as an average whole, to the noise generated by medium range jet aircraft" now in use. Id. at 376. Stretched versions of current jets, on the other hand, may aggravate the noise problem. Id. at 378.

111 Id. at 42 (prepared statement of Alfred J. Eggers, Jr., Deputy Associate Administrator for Advanced Research and Technology). $100 \mathrm{PNdB}$ is about the level of speech interference. Id. at 335 (testimony of Charles W. Harper, Director, Aeronautics Division, Office of Advanced Research and Technology, NASA).

112 As introduced, S. 707 and H.R. 3400 would delegate the regulatory authority to the Secretary of Transportation, not the Administrator of the FAA. But there seems to be little doubt, at least within the FAA, that the authority would be further delegated to them.

113 On an analogous point with regard to the safety regulation of nuclear reactors, see Green, Nuclear Technology and the Fabric of Government, 33 GEO. WasH. L. REv. 121 (1964).

114 The NASA presentation to the House Aeronautics and Space Committee includes a chart on the noise problem at a typical metropolitan airport. It shows that one mile to the side of the midpoint of the runway the composite noise rating (PNdB level adjusted for the number of operations) has exceeded 100 since about 1960 and that the number of operations has doubled in the last ten years. Hotlse 1968 NASA Authorization Hearings, supra note 2, pt. 4 , at 43 . 
One possible check on the FAA is to provide for a local voice in determining noise abatement procedures around airports. There are several forms such a provision might take. The simplest would require the FAA to take local preferences into account in establishing flight paths and procedures and designating airways. ${ }^{115} \mathrm{~A}$ greater local role could be assured by granting localities permissive authority to adopt noise standards, subject to veto on a finding that the enforcement of the standards would adversely affect aviation safety or that compliance would be economically impracticable. The Administrator would be given the power to suspend a local regulation pending the outcome of a hearing on its impact on safety and the feasibility of compliance. ${ }^{116}$

The latter type of provision would have to be carefully drafted to avoid difficulties under the $A s h b a c k e r$ doctrine, ${ }^{117}$ since noise standards adopted by one locality might force flights over other localities which had not yet acted. Difficulties of coordination among numerous localities would frequently be worked out by compromise among them, obviating the necessity for the Administrator to seek federal nullification of standards adopted by only one of the communities and the intervention of the others in the hearing. The legislation might even require regional action by all of the affected communities whenever there is more than one that wishes to regulate. ${ }^{118}$

\section{CONCLUSION}

There has been little indication that the federal agencies which regulate air transportation are willing to commit themselves to a policy of minimizing its environmental impact. Despite some of the rhetoric of the Department of Transportation, the FAA has done little in this area. Indeed, it has declared its powerlessness to regulate aircraft noise effectively while seeking legislation which it apparently intends to

115 A provision requiring that fair consideration be given to the interests of communities in or near which air operations are authorized or airways established, for example.

116 Such hearings might properly be held before the National Transportation Safety Board.

117 Ashbacker Radio Corp. v. FCC, 326 U.S. 327 (1945). Cf. American Airlines, Inc. v. Town of Hempstead, 272 F. Supp. 226, 231-32, 236 (E.D.N.Y. 1967).

118 This might necessitate state (or even multi-state) enabling legislation to create a regional authority with a very limited role. Such a complicated procedure, and the designation of a regional body for this purpose, seems unnecessary if local governments could accomplish the same result by informal coordination. At first glance, the test used in the Hempstead case for the constitutionality of a local ordinance-consideration of the questioned ordinance "as if it were one of a set of ordinances each enacted by a bordering town, and all, taken together, encompassing the airport" (272 F. Supp. at 231) -seems to create an incentive for this cooperation. But, as applied in that case, the result would be that only the status quo could be adopted. The problem of dealing with multiple jurisdictions is not so easily solved. 
utilize to preserve the status quo. The $\mathrm{CAB}$ has yet to accept any responsibility for the environmental consequences of the activity it regulates.

The problem of aircraft noise, like other environmental effects of government-sponsored or government-regulated economic activity, is not amenable to one best solution dependent on analyses of its dollar costs. It turns primarily on policy choices which are only imperfectly quantifiable. Standards for regulating aircraft noise depend more on a policy judgment as to the importance of maintaining or improving the character of particular areas relative to the importance of improved air transportation than on the quantifiable costs of aircraft noise contrasted with the quantifiable benefits derived from air transportation. The decision is essentially a legislative one. If it is to be made in administrative proceedings, it is incumbent upon the regulatory agencies to assure that environmental issues are considered. This might best be done through participation by a governmental agency with the specific function of representing and promoting the public interest in the quality of the environment and the resources and expertise to do the job properly. Prospects for the establishment of such an agency, however, are not bright. In the meantime, in the particular area of air transportation, the $\mathrm{CAB}$ and the Department of Transportation have a responsibility for assuring that their regulatory activities serve the interests of the public as a whole. Their commitment to minimizing the intrusiveness of air transportation is badly needed. 